\title{
Anteseden Return on Asset (ROA) pada Bank BUMN Indonesia
}

\author{
Andi Tenriola \\ Manajemen, STIEM Bongaya \\ Email : andi.tenri@stiem-bongaya.ac.id
}

Diterima: 2 Februari 2019; direvisi: 10 April 2019; dipublikasikan: 09 Mei 2019

(C2019 -Bongaya Journal of Research in Management STIEM Bongaya. Ini adalah artikel dengan akses terbuka dibawah licenci CC BY-NC-4.0 (https://creativecommons.org/licenses/by-nc/4.0/ ).

\begin{abstract}
This study aims to examine and analyze the effect of Capital Adequacy Ratio (CAR), Operating Expenses and Cost Efficiency (BOPO) and Loan to Deposit Ratio (LDR) to Return on assets (ROA). Return on assets (ROA) or profitability is one indicator that can be used to measure bank performance. The population used in this study is state-owned banks registered with Bank Indonesia during the 2014-2018 period. In this study the sampling technique used total sampling techniques using quarterly financial statements owned (1) PT. BNI (Persero), Tbk (2) Bank BRI (Persero), Tbk, (3) PT Bank Mandiri (Persero), Tbk; and (4) PT Bank BTN (Persero) so that with the sample, the number of samples in this study were (4 Quarter $\times 5$ Years of Observation $\times 4$ BUMN Banks $=80$ panel data units). The results of multiple regression analysis provide evidence that CAR has a significant positive effect on ROA. Operational efficiency and cost efficiency (BOPO) has a significant negative effect on return on assets (ROA). LDR has a significant negative effect on ROA. For the biggest contribution proven in $C A R$, that CAR has a dominant effect on ROA.
\end{abstract}

Keywords: CAR, BOPO, LDR, ROA, BUMN Banking

\begin{abstract}
ABSTRAK
Penelitian ini bertujuan untuk menguji dan menganalisis pengaruh Capital Adequacy Ratio (CAR), Operating Expenses dan Cost Efficiency (BOPO) dan Loan to Deposit Ratio (LDR) terhadap Return on asset (ROA). Return on asset (ROA) atau profitabilitas merupakan salah satu indikator yang dapat digunakan untuk mengukur kinerja bank. Populasi yang digunakan dalam penelitian ini adalah Bank BUMN yang terdaftar di Bank Indonesia selama periode 2014-2018. Pada penelitian ini teknik pengambilan sampel menggunakan teknik total sampling dengan menggunakan laporan keuangan Triwulan yang dimiliki (1) PT. Bank BNI (Persero), Tbk (2) PT bank BRI (Persero), Tbk, (3) PT Bank Mandiri (Persero), Tbk; dan (4) PT Bank BTN (Persero) sehingga dengan sampel tersebut, maka jumlah sampel dalam penelitian ini sebanyak (4 Triwulan x 5 Tahun Pengamatan x 4 Bank BUMN $=80$ unit data panel). Hasil multiple regression analysis memberikan bukti bahwa CAR berpengaruh positif signifikan terhadap ROA. Operational efficiency and cost efficiency (BOPO) berpengaruh negatif signifikan terhadap return on asset (ROA). LDR berpengaruh negatif signifikan terhadap ROA. Untuk kontribusi terbesar dibuktikan pada CAR, bahwa CAR berpengaruh dominan terhadap ROA.
\end{abstract}

Kata Kunci: CAR, BOPO, LDR, ROA, Bank BUMN 



\section{Pendahuluan}

Perekonomian suatu Negara dapat tumbuh dan bersaing dengan Negara lainnya apabila didukung dengan kontribusi segala unit bisnis yang dimiliki negara tersebut, salah satunya adalah perbankan milik pemerintah (BUMN). Lembaga Perbankan bertindak sebagai perantara antara pemasok dan penerima dana dengan menambah aliran modal dari unit ekonomi surplus ke defisit. Kompetensi inti dari bank tidak hanya melekat pada pertukaran dana tetapi juga dalam kemampuan mereka untuk mengelola risiko kredit. Pendapatan bunga, yang dianggap sebagai sumber utama pendapatan perbankan, dihasilkan untuk mengkompensasi biaya operasi peminjaman, Pada bahagian lainnya perbankan dalam menjalankan aktivitasnya memiliki risiko yang sangat tinggi dalam mengelola dana masyarakat melalui pemberian kredit, pembelian surat-surat berharga dan investasi lainnya (DeYoung dan Rice, 2004).

Hingga akhir Tahun 2018 perbankan pemerintah yang terdiri Bank Mandiri (BMRI), Bank Rakyat Indonesia (BBRI), Bank Negara Indonesia (BBNI), dan Bank Tabungan Negara (BBTN) mencatatkan pertumbuhan pendapatan dan laba yang positif. Diantara keempat bank milik pemerintah tersebut bank yang memiliki jumlah pendapatan paling besar adalah Bank Rakyat Indonesia (BBRI) dengan total pendapatan sebesar $\mathrm{Rp}$ 77,6 triliun (jika dibandingkan tahun 2017 meningkat 6,3\%), Pada posisi kedua perolehan pendapatan terbesar, dicapai Bank Mandiri (BMRI) dengan jumlah pendapatan sebesar Rp. 54,62 triliun (jika dibandingkan tahun 2017 meningkat 5,07\%). Berikutnya Bank Negara Indonesia (BBNI) dengan jumlah pendapatan mencapai Rp 35,45 triliun (jika dibandingkan tahun 2017 meningkat 11\%). Terakhir Bank BUMN lain yang juga memiliki kinerja positif adalah Bank Tabungan Negara (BBTN). Bank dengan valuasi pendapatan sebesar Rp 11,9 triliun (jika dibandingkan tahun 2017 meningkat $3,65 \%)$

(https://keuangan.kontan.co.id/, 2019).

Kenaikan pendapatan bank BUMN berbanding terbalik dengan yang diperoleh ketiga bank swasta terbesar, yaitu Bank Panin Tbk (PNBN), Bank OCBC NISP Tbk (NISP), dan Bank Danamon Tbk (BDMN), dari ketiga bank swasta tersebut, hanya Bank OCBC NISP
Tbk (NISP) yang mencatat pertumbuhan kinerja positif jika dibandingkan antara akhir semester pertama 2018 dan akhir semester I 2017. Perolehan laba Bank OCBC NISP Tbk (NISP) memperoleh kenaikan laba 18,25\% menjadi $\mathrm{Rp} 1,3$ triliun (periode semester pertama 2018, jika dibandingkan periode yang sama tahun 2017). Kemudian Bank Danamon Tbk (BDMN) mengalami penurunan laba menjadi Rp 2,03 triliun (turun 1,3\% jika dibandingkan periode yang sama tahun 2017). selanjutnya Bank Panin Tbk (PNBN) yang juga mencatat penurunan laba menjadi Rp 1,2 triliun (turun 8,58\% jika dibandingkan periode yang sama tahun 2017) (https://keuangan.kontan.co.id/, 2019).

Fakta lapangan tersebut menjadi alasan peneliti untuk menganalisis kemampuan bank BUMN dalam menghasilkan laba (profitabilitas). Rasio profitabilitas yang penting bagi bank adalah return on asset (ROA). ROA penting bagi bank karena ROA digunakan untuk mengukur efektivitas bank dalam menghasilkan keuntungan dengan memanfaatkan aktiva yang dimilikinya. ROA merupakan rasio antara laba sesudah pajak terhadap total asset. Semakin tinggi ROA perbankan maka semakin tinggi kinerja perbankan, karena tingkat kembalian (return) semakin besar (Husnan, 2013).

Profitabilitas merupakan harapan dari perbankan dalam menjaga dan mempertahankan aktivitas suatu bank untuk jangka panjang, profitabilitas menggambarkan kondisi yang baik dimasa yang akan datang. Bank wajib meningkatkan profitabilitasnya, hal ini disebabkan semakin tinggi profitabilitas bank maka keberlangsungan usaha bank semakin terjamin. Return On Assets (ROA) digunakan sebagai proksi dari profitabilitas bank karena Bank Indonesia sebagai pembina dan pengawas perbankan lebih mengutamakan nilai profitabilitas suatu bank yang diukur dari aset yang dananya berasal sebagian besar dana simpanan masyarakat. Semakin tinggi ROA bank maka semakin tinggi keuntungan yang diperoleh bank sehingga posisi bank tersebut dari segi penggunaan asset semakin baik (Dendawijaya, 2009:118).

Aspek permodalan bank merupakan salah satu aspek penting untuk mengetahui kemampuan bank dalam memproteksi kerugian. Kecukupan modal dapat diukur dengan menggunakan rasio Capital Adequacy Ratio (CAR). CAR diartikan sebagai cadangan 
modal yang harus ada pada sebuah bank minimal $8 \%$ sesuai dengan peraturan bank Indonesia. Capital Adequacy Ratio (CAR) adalah rasio kecukupan modal yang berfungsi menampung risiko kerugian yang dihadapi oleh bank. Semakin tinggi Capital Adequacy Ratio (CAR) maka semakin baik kemampuan bank tersebut untuk menanggung risiko dari setiap kredit/aktiva produktif yang berisiko.

Semakin besar CAR, maka semakin besar kesempatan bank dalam menghasilkan laba karena dengan modal besar yang dimiliki oleh bank. Modal yang besar membantu manajemen bank untuk lebih leluasa dalam menempatkan dananya ke dalam aktivitas investasi yang menguntungkan. Rendahnya CAR dikarenakan peningkatan ekspansi aset berisiko yang tidak diimbangi dengan penambahan modal yang menurunkan kesempatan bank untuk berinvestasi sehingga membuat kepercayaan masyarakat menjadi turun yang berpengaruh pada penurunan profitabilitas perbankan. Pembentukan dan peningkatan aktiva bank sebagai penghasil keuntungan harus memperhatikan kepentingan-kepentingan pihak ketiga sebagai nasabah bank (Darmawi H., 2014).

Hasil penelitian terdahulu memberikan bukti bahwa Capital Adequacy Ratio (CAR) berpengaruh positif signifikan terhadap ROA (Rahmah, M. N., 2019; Gustin, A. P. 2019). Hasil tersebut menjelaskan bahwa semakin besar CAR, maka semakin besar kesempatan bank dalam menghasilkan laba karena dengan modal besar yang dimiliki oleh bank maka pihak manajemen bank memiliki banyak pilihan dalam menempatkan dananya ke dalam aktivitas investasi yang menguntungkan. Hasil yang berbeda ditunjukkan pada hasil penelitian lainnya, bahwa Capital Adequacy Ratio (CAR) berpengaruh positif tidak signifikan terhadap ROA ROA (Purnamasari, Y., \& Mudakir, B., 2019; Setiawan, M., Amboningtyas, D., \& Aryanti, R. P., 2019; Rachmawati, S., \& Marwansyah, S. 2019; Sari, D. N., Sriwidodo, U., \& Indriastuti, D. R., 2019; Kokoh dkk., $\underline{2019)}$.

Rasio Operating Expenses dan Cost Efficiency (BOPO) merupakan parameter yang digunakan dalam menunjukkan efisiensi bank dalam menjalankan usaha pokoknya, terutama kredit, dimana sampai saat ini pendapatan bank-bank di Indonesia masih didominasi oleh pendapatan bunga kredit. Semakin kecil BOPO menunjukkan semakin efisien bank dalam menjalankan aktivitas usahanya. Bank yang sehat rasio BOPO $<1$ sebaliknya bank yang kurang sehat rasio $\mathrm{BOPO}>1$. Operating Expenses dan Cost Efficiency (BOPO) bank sangat tinggi, maka berdampak terhadap rendahnya nilai ROA bank. Fakta empiris menunjukkan bahwa operational efficiency and cost efficiency (BOPO) berpengaruh negatif signifikan terhadap return on asset (ROA). Hasil ini menunjukkan bahwa BOPO yang rendah terbukti mampu meningkatkan return on asset (ROA) bank (Kokoh dkk., 2019; Setiawan, M., Amboningtyas, D., \& Aryanti, R. P., 2019). Hasil tersebut berbeda dengan temuan peneliti lainnya, bahwa operational efficiency and cost efficiency (BOPO) berpengaruh negatif tidak signifikan terhadap return on asset (ROA) (Rachmawati, S., \& Marwansyah, S., 2019).

Kegiatan bank tidak terlepas dari penyaluran dana kepada nasabah yang dikenal dengan Loan to Deposit Ratio atau LDR. Loan to Deposit Ratio merupakan rasio antara jumlah kredit yang disalurkan terhadap dana pihak ketiga yang dihimpun oleh bank. Semakin besar jumlah dana yang disalurkan kepada nasabah dalam bentuk kredit maka jumlah dana yang menganggur berkurang dan penghasilan bunga yang diperoleh akan meningkat. Hal ini tentunya akan meningkatkan LDR sehingga Return on Asset bank juga meningkat. loan to deposit ratio (LDR) adalah rasio keuangan yang berhubungan dengan aspek likuiditas. Loan to deposit ratio (LDR) digunakan untuk mengukur kemampuan bank dalam membayar kewajibannya, rasio ini menunjukkan jumlah kredit yang diberikan yang dibiayai dengan dana pihak ketiga.

Hasil penelitian terdahulu menunjukkan bahwa loan to deposit ratio (LDR) berpengaruh positif signifikan terhadap ROA (Sari, D. N., Sriwidodo, U., \& Indriastuti, D. R., 2019). Temuan tersebut memperoleh bantahan dari peneliti lainnya, bahwa LDR berpengaruh negatif tidak signifikan terhadap ROA (Fajri, R., \& Seftarita, C., 2019). LDR berpengaruh negatif signifikan terhadap ROA (Kokoh dkk., 2019). LDR berpengaruh positif tidak signifikan terhadap ROA (Putra, P. S., \& Juniarti, S., 2019).

\section{Tinjauan Pustaka}

\subsection{Pengertian bank}

Pasal 1 ayat 2 Undang-undang Republik Indonesia nomor 10 Tahun 1998 menjelaskan 
bahwa bank adalah sebuah badan usaha yang menghimpun dana dari masyarakat dalam bentuk simpanan dan menyalurkannya kepada masyarakat dalam bentuka kredit atau bentukbentuk lainnya dalam rangka meningkatkan taraf hidup rakyat banyak. Secara sederhana pengertian bank, menurutkan bank dapat diartikan sebagai lembaga keuangan dimana kegiatan utamanya adalah menghimpun dana dari masyarakat serta menyalurkan kembali dana tersebut ke masyarakat serta memberikan jasa bank lain (Kasmir, 2014).

\subsection{Pengertian profitabilitas (ROA)}

Profitabilitas merupakan rasio yang menggambarkan kemampuan perusahaan dalam mendapatkan laba melalui semua kemampuan dan sumber yang ada seperti kegiatan penjualan, kas, modal, jumlah karyawan,jumlah cabang dan sebagainya. Rasio profitabilitas merupakan rasio untuk menilai kemampuan perusahaan dalam mencari keuntungan. Rasio ini juga memberikan ukuran tingkat efektivitas manajemen suatu perusahaan (Kasmir, 2014). Profitabilitas adalah rasio yang digunakan untuk mengukur kemampuan perusahaan dalam mendapatkan laba. Profitabilitas suatu bank diukur dengan kemampuan menggunakan aktivanya secara produktif, dengan demikian profitabilitas suatu bank dapat diketahui dengan membandingkan antara laba yang diperoleh dalam suatu periode dengan jumlah aktiva atau jumlah modal bank tersebut.

ROA adalah salah satu indikator untuk mengukur kinerja keuangan perusahaan dan merupakan rasio profitabilitas yang digunakan untuk mengukur efektivitas perusahaan dalam menghasilkan keuntungan dengan memanfaatkan total aktiva yang dimilikinya (Darmawi H., 2014: 56). Berdasarkan penilaian kesehatan bank (Bank Indonesia), standar ROA yang baik dan harus dipatuhi oleh bank adalah sekitar > 1,5\%, agar bank tersebut tidak digolongkan sakit. Return on Assets (ROA) dapat dihitung dengan menggunakan rumus sebagai berikut (Peraturan Bank Indonesia Nomor 14/ 15 /PBI/2012 Tentang Penilaian Kualitas Aset Bank Umum):

$$
R O A=\frac{\text { Laba sebelum pajak }}{\text { Rata }- \text { rata Total Asset }} \times 100 \%
$$

\subsection{Pengertian Capital Adequacy Ratio (CAR) \\ CAR merupakan indikator terhadap} kemampuan bank untuk menutupi kerugiankerugian bank yang disebabkan oleh aktiva yang berisiko (Dendawijaya, 2011: 121). Capital Adequacy Ratio (CAR) dapat dihitung dengan menggunakan rumus sebagai berikut (Peraturan Bank Indonesia Nomor 14/ 15 /PBI/2012 Tentang Penilaian Kualitas Aset Bank Umum):

$$
C A R=\frac{\text { Modal }}{\text { Aktiva Tertimbang menurut Risiko }} \times 100
$$

\subsection{Pengertian Operational Efficiency and Cost Efficiency (BOPO)}

Biaya operasional merupakan biaya yang dikeluarkan oleh pihak bank dalam menjalankan aktivitasnya sehari-hari meliputi : biaya gaji, biaya pemasaran, biaya bunga. Sedangkan pendapatan operasional merupakan pendapatan yang diterima oleh pihak bank yang diperoleh dari penyaluran kredit dalam bentuk suku bunga (Dendawijaya, 2009: 129). Rasio Biaya Operasional Terhadap Pendapatan Operasional (BOPO) merupakan perbandingan antara biaya operasional dengan pendapatan operasional dalam mengukur tingkat efisiensi dan kemampuan bank dalam melakukan kegiatan operasinya. Semakin kecil rasio biaya (beban) operasionalnya akan lebih baik, karena bank yang bersangkutan dapat menutupi biaya (beban) operasional dengan pendapatan operasionalnya (Rivai, V., Basir, S., Sudarto, S., \& Veithzal, A. P., 2013).

Bank yang efisien dalam menekan biaya operasionalnya dapat mengurangi kerugian akibat ketidak efisienan bank dalam mengelolah usahanya sehingga laba (ROA) yang diperoleh juga semakin meningkat. Sebaliknya, setiap peningkatan biaya operasional akan berakibat pada berkurangnya laba sebelum pajak yang pada akhirnya akan menurunkan ROA. Kriteria Efisiensi / Sehat adalah $<93.5 \%$ (sehat) dan $>93,5 \%$ (tidak sehat). Operational Efficiency and Cost Efficiency (BOPO) dapat dihitung dengan menggunakan rumus sebagai berikut (Peraturan Bank Indonesia Nomor 14/ 15 /PBI/2012 Tentang Penilaian Kualitas Aset Bank Umum): 


$$
B O P O=\frac{\text { Biaya Operasional }}{\text { Pendapatan Bank }} \times 100
$$

\subsection{Pengertian Loan to Deposit Ratio (LDR)}

LDR merupakan perbandingan antara total kredit yang telah diberikan oleh bank dengan total dana pihak ketiga yang dapat dihimpun oleh bank (Kasmir. 2014: 95). Loan to Deposit Ratio (LDR) dapat dihitung dengan menggunakan rumus sebagai berikut (Peraturan Bank Indonesia Nomor 14/ 15 /PBI/2012 Tentang Penilaian Kualitas Aset Bank Umum):

$$
L D R=\frac{\text { Kredit }}{\text { Dana Pihak Ketiga }} \times 100
$$

\section{Metode Penelitian}

Penelitian ini merupakan penelitian kuantitatif yaitu penelitian yang menggunakan data sekunder untuk menguji bagaimana pengaruh kecukupan modal, risiko pembiayaan, likuiditas dan beban operasional terhadap profitabilitas. Populasi yang digunakan dalam penelitian ini adalah bank BUMN yang terdaftar di Bank Indonesia selama periode 2014-2018. Pada penelitian ini teknik pengambilan sampel menggunakan metode total sampling dengan menggunakan laporan keuangan Triwulan yang dimiliki (1) PT. Bank BNI (Persero), Tbk (2) PT bank BRI (Persero), Tbk, (3) PT Bank Mandiri (Persero), Tbk; dan (4) PT Bank BTN (Persero) sehingga dengan sampel tersebut, maka jumlah sampel dalam penelitian ini sebanyak (4 Triwulan x 5 Tahun Pengamatan $\mathrm{x} 4$ Bank BUMN $=80$ unit data panel). Analisis data yang digunakan dalam studi ini adalah multiple regression analysis yang dilakukan bertujuan untuk menguji kontribusi variabel bebas terhadap variabel terikat, dengan terlebih dahulu melakukan evaluasi dengan menggunakan uji Blue (best, linear, unbiased, estimated) melalui uji normalitas data, uji autokorelasi, uji multikolinearitas dan uji heteroskedastisitas. Tahapan analisis berikutnya adalah melakukan Fisher test yang bertujuan untuk mengetahui kelayakan model regresi yang dibangun. Selanjutnya setelah model dinyatakan layak (goodness of fit model) maka dilakukan Student test untuk mengetahui apakah hipotesis dinyatakan diterima atau ditolak. Terakhir dilakukan pengujian determinasi $\left(\mathrm{R}^{2}\right)$ untuk mengetahui kontribusi dari masingmasing variabel independen terhadap variabel dependen dengan mengalikan nilai koefisien korelasi dengan nilai koefisien beta dari masing-masing variabel bebas terhadap variabel terikat.

\section{Hasil Penelitian}

4.1. Uji Blue (best, linear, unbiased, estimated)

4.1.1. Uji normalitas data

Uji normalitas dilakukan dengan menggunakan uji statistik (KolmogorovSmimov). Dasar pengambilan keputusan dalam uji statistik Kolmogorov-Smimov yakni jika nilai signifikan lebih besar dari 0.05 maka data tersebut berdistribusi normal. Hasil dari pengujian normal tersebut dapat dilihat pada Tabel 1.

Nilai Kolmogorov-Smimov sebesar $0.083>0.05$ dan nilai $\mathrm{p}$-value $=0.200>0.05$ sehingga berdasarkan hasil tersebut maka nilai tersebut dapat disimpulkan bahwa data yang diuji berdistribusi normal.

\subsubsection{Uji autokorelasi}

Uji autokorelasi menurut (Ghozali, 2011:110) dilakukan dengan tujuan untuk mendeteksi ada atau tidaknya autokorelasi pada model regresi, pada model ini akan digunakan uji Durbin-Watson (DW-Test). Model regresi yang baik adalah model regresi yang bebas dari autokorelasi. Dalam pengambilan keputusan uji autokorelasi dengan menggunakan Durbin Watson Test (DW-Test).

Berdasarkan hasil uji autokorelasi pada Tabel 2 menunjukkan bahwa nilai dl DurbinLower du (batas bawah) $=1.560<$ DurbinWatson $=1.629<$ Durbin-upper $=1.715$ sehingga keputusan hasil uji autokorelasi tersebut adalah tidak ada autokorelasi positif atau negatif. 


\begin{tabular}{llr}
\hline & One-Sample Kolmogorov-Smirnov Test & \\
\hline & & Unstandardized Residual \\
$\mathrm{N}$ & & 80 \\
Normal Parameters & Mean & .0000000 \\
& Std. Deviation & 23.61863809 \\
Most Extreme Differences & Absolute & .083 \\
& Positive & .083 \\
& Negative & -.057 \\
Test Statistic & & .083 \\
Asymp. Sig. (2-tailed) & & $.200^{\text {c,d }}$ \\
\hline
\end{tabular}

\subsubsection{Uji multikolinearitas}

Apabila nilai VIF $<10$ dan nilai tolerance mendekati 1, maka diambil kesimpulan bahwa model regresi tersebut tidak terdapat problem multikolinearitas (Ghozali, 2011:113). Hasil pengujian dapat dilihat pada tabel 3 .

\subsubsection{Uji heteroskedastisitas.}

Uji heteroskedastisitas dilakukan untuk menguji apakah dalam sebuah model regresi, terjadi ketidaksamaan varians dari residual dari satu pengamatan ke pengamatan yang lain. Jika varians dari residual dari satu pengamatan ke pengamatan yang lain tetap, maka disebut Homoskedastisitas. Dan jika varians berbeda, disebut Heterokedastisitas Model regresi yang baik adalah tidak terjadi heteroskedastisitas (Ghozali, 2011:117). Hasil uji heteroskedastisitas dalam penelitian ini dapat dilihat pada tabel 4 .

Tabel 2 Hasil Uji Autokorelasi

Model Summary ${ }^{b}$

\begin{tabular}{lrrr}
\multicolumn{1}{c}{ Model } & Durbin-Lower & Durbin-Watson & Durbin-upper \\
\hline 1 & 1.560 & 1.629 & 1.715 \\
a. Predictors: (Constant), X3, X2, X1 & & \\
b. Dependent Variable: $\mathrm{Y}$ & & \\
\hline
\end{tabular}

Berdasarkan hasil uji heteroskedastisitas pada tabel 4. menunjukkan bahwa variabel independen dalam penelitian ini yaitu CAR, BOPO dan LDR memiliki nilai $\mathrm{p}$-value $=>0.05$ sehingga dapat disimpulkan bahwa data dalam penelitian ini tidak terdapat heteroskedastisitas.

\subsection{Uji Koefisien determinasi}

Nilai $\mathbf{R}^{2}$ mempunyai interval 0 sampai $1(0$ $\leq \mathrm{R} 2 \leq 1$ ). Jika $\mathrm{R}^{2}$ bernilai besar (mendekati 1) berarti variabel independen dapat memberikan hampir semua informasi yang dibutuhkan untuk memprediksi variabel dependen. Sedangkan jika $\mathrm{R}^{2}$ bernilai kecil berarti kemampuan variabel bebas dalam menjelaskan variabel dependen sangat terbatas.

Hasil tersebut menunjukkan bahwa kontribusi total pengaruh variabel independen terhadap variabel dependen sebesar 0.346 atau $34.60 \%$ yang dicerminkan melalui CAR dengan jumlah kontribusi sebesar 0.171 atau sebesar $17.10 \%$, BOPO 0.136 atau sebesar $13.60 \%$ dan LDR sebesar 0.039 atau 3,90\%.

\subsection{Uji Kelayakan Model (Fisher test)}

Penggunaan uji-f dilakukan untuk menilai apakah model yang disusun oleh peneliti layak dan dapat dilanjutkan ke penelitian lebih lanjut. Dalam penelitian ini yaitu kualitas laba terhadap Nilai Perusahaan, dasar pengambilan keputusan terbukti atau tidaknya hipotesis yang diajukan yaitu jika nilai $\mathrm{f}_{\text {-hitung }}>\mathrm{f}_{\text {-tabel }}$ dan pada tingkat signifikansi $<0.05$, maka model penelitian yang disusun oleh peneliti memenuhi uji kelayakan model.

Hasil tersebut menunjukkan nilai f-hitung $=$ $13.428>$ f-tabel $=2,724$. Sehingga dapat dinyatakan bahwa model tersebut telah memenuhi goodness of fit model.

\subsection{Uji t-statistik}


Uji t-statistik dilakukan untuk membuktikan hipotesis yang diajukan, apakah yang menjadi variabel bebas yaitu CAR, BOPO

Tabel 3 Hasil Uji Multikolinearitas

Coefficients $^{\mathrm{a}}$

\begin{tabular}{llll}
\hline & & \multicolumn{3}{c}{ Collinearity Statistics } \\
\cline { 3 - 4 } Model & & Tolerance & VIF \\
\hline 1 & (Constant) & & \\
& & & .436 \\
& $\mathrm{X}_{1}(\mathrm{CAR})$ & .438 & 2.292 \\
& $\mathrm{X}_{2}(\mathrm{BOPO})$ & .917 & 2.284 \\
& $\mathrm{X}_{3}(\mathrm{LDR})$ & & 1.090 \\
\hline
\end{tabular}

dan LDR berpengaruh terhadap Return on asset/ ROA. Hasil pengujian regresi ganda dalam penelitian ini dapat dilihat pada tabel 7 .

Mengacu pada hasil tersebut, maka dapat digunakan persamaan regresi ganda sebagai

$$
\begin{aligned}
Y(R O A)=10 . & 487+0,319(C A R) \\
& -0,633(\text { BOPO }) \\
& -0,307(\text { LDR }) \\
& +3,153(\text { Standar Error })
\end{aligned}
$$

\begin{tabular}{|c|c|c|c|}
\hline \multicolumn{4}{|c|}{ Coefficients $^{\mathrm{a}}$} \\
\hline \multicolumn{2}{|r|}{ Model } & $\mathrm{t}$ & Sig. \\
\hline 1 & (Constant) & 9.263 & .000 \\
\hline & $\mathrm{X}_{1}(\mathrm{CAR})$ & -.110 & .403 \\
\hline & $\mathrm{X}_{2}(\mathrm{BOPO})$ & -1.891 & .062 \\
\hline & $\mathrm{X}_{3}(\mathrm{LDR})$ & -1.878 & .064 \\
\hline & ent Variable: Hetero & & \\
\hline
\end{tabular}

berikut:

$$
Y=\alpha+\beta_{1} X_{1}+\beta_{2} X_{2}+\beta_{3} X_{3}+e
$$

Tabel 4 Hasil Uji Heteroskedastisitas

\subsection{Pembahasan}

\subsubsection{CAR berpengaruh positif signifikan} terhadap ROA

Berdasarkan hasil analisis regresi linear ganda diperoleh nilai t-hitung sebesar $2.503>\mathrm{t}$ tabel sebesar 1.9904 dengan $p$ value $0,016<$ 0,05 . Hal ini menjelaskan bahwa $\mathrm{H} 0$ ditolak dan $\mathrm{Ha}$ diterima sehingga hipotesis pertama dinyatakan diterima bahwa CAR berpengaruh positif signifikan terhadap ROA (Ha). Hasil penelitian ini mendukung temuan peneliti terdahulu, bahwa Capital Adequacy Ratio (CAR) berpengaruh positif signifikan terhadap ROA (Rahmah, M. N., 2019; Gustin, A. P. 2019). Hasil tersebut menjelaskan bahwa semakin besar CAR, maka semakin besar kesempatan bank dalam menghasilkan laba karena dengan modal besar yang dimiliki oleh bank maka pihak manajemen bank memiliki banyak pilihan dalam menempatkan dananya ke dalam aktivitas investasi yang menguntungkan. Temuan penelitian ini menolak hasil penelitian lainnya, bahwa Capital Adequacy Ratio (CAR) berpengaruh positif tidak signifikan terhadap ROA ROA (Purnamasari, Y., \& Mudakir, B., 2019; Setiawan, M., Amboningtyas, D., \& Aryanti, R. P., 2019; Rachmawati, S., \& Marwansyah, S. 2019; Sari, D. N., Sriwidodo, U., \& Indriastuti, D. R., 2019; Kokoh dkk., 2019).

\subsubsection{BOPO berpengaruh negatif signifikan terhadap ROA}

Berdasarkan hasil analisis regresi linear ganda diperoleh nilai t-hitung sebesar $-4.513<$ t-tabel sebesar 1.9904 dengan $p$ value $0,000<$ 
0,05. Hal ini menjelaskan bahwa Ha ditolak dan H0 diterima sehingga hipotesis kedua dinyatakan diterima bahwa CAR berpengaruh negatif signifikan terhadap ROA (H0). Hasil penelitian mendukung temuan peneliti terdahulu bahwa operational efficiency and cost efficiency (BOPO) berpengaruh negatif signifikan terhadap return on asset (ROA) (Kokoh dkk., 2019; Setiawan, M., Amboningtyas, D., \& Aryanti, R. P., 2019).

Tabel 5 Koefisien Determinasi

\begin{tabular}{|c|c|c|c|c|c|c|}
\hline Model & $\mathrm{R}$ & $\begin{array}{c}\mathrm{R} \\
\text { Square }\end{array}$ & $\begin{array}{c}\text { Variabel } \\
\text { independent }\end{array}$ & $\begin{array}{l}\text { Nilai Koefisien } \\
\text { Korelasi }\end{array}$ & $\begin{array}{c}\text { Nilai Beta } \\
\text { Standardized }\end{array}$ & $\begin{array}{c}\text { Kontribusi variabel } \\
\text { independen }\end{array}$ \\
\hline \multirow{5}{*}{1} & \multirow{5}{*}{$.589^{\mathrm{a}}$} & \multirow{5}{*}{0.346} & $\mathrm{X}_{1}(\mathrm{CAR})$ & 0.536 & 0.319 & 0.171 \\
\hline & & & $\mathrm{X}_{2}(\mathrm{BOPO})$ & -0.215 & -0.633 & 0.136 \\
\hline & & & & & & \\
\hline & & & $\mathrm{X}_{3}(\mathrm{LDR})$ & -0.128 & -0.307 & 0.039 \\
\hline & & & & & TOTAL & 0.346 \\
\hline
\end{tabular}

Menolak temuan peneliti lainnya, bahwa operational efficiency and cost efficiency (BOPO) berpengaruh negatif tidak signifikan terhadap return on asset (ROA) (Rachmawati, S., \& Marwansyah, S., 2019). Negative signifikannya hasil penelitian ini menunjukkan bahwa BOPO yang rendah terbukti mampu meningkatkan return on asset (ROA) bank

Tabel 6 Goodness of Fit Model

ANOVA $^{\mathrm{a}}$

\begin{tabular}{llrrrrr}
\hline Model & & Sum of Squares & df & Mean Square & F & Sig. \\
\hline 1 & Regression & 23361.330 & 3 & 7787.110 & 13.429 & $.000^{\mathrm{b}}$ \\
& Residual & 44069.365 & 76 & 579.860 & & \\
& Total & 67430.695 & 79 & & & \\
\hline
\end{tabular}

\subsubsection{LDR berpengaruh negatif signifikan terhadap ROA}

Hasil analisis regresi linear ganda diperoleh nilai t-hitung sebesar $-3.167<\mathrm{t}$-tabel sebesar 1.9904 dengan $p$ value $0,002<0,05$. Hal ini menjelaskan bahwa $\mathrm{HO}$ ditolak dan Ha diterima sehingga hipotesis ketiga dinyatakan ditolak bahwa LDR berpengaruh positif signifikan terhadap ROA (H0). Hasil penelitian ini relevan dengan temuan Kokoh dkk. (2019) bahwa LDR berpengaruh negatif signifikan terhadap ROA. Menolak temuan peneliti lainnya bahwa loan to deposit ratio (LDR) berpengaruh positif signifikan terhadap ROA (Sari, D. N., Sriwidodo, U., \& Indriastuti, D. R., 2019). LDR berpengaruh negatif tidak signifikan terhadap ROA (Fajri, R., \& Seftarita, C., 2019). LDR berpengaruh positif tidak signifikan terhadap ROA (Putra, P. S., \& Juniarti, S., 2019). Hasil penelitian ini memberikan penjelasan bahwa semakin kecil jumlah dana yang disalurkan kepada nasabah dalam bentuk kredit maka jumlah dana yang menganggur berkurang dan penghasilan bunga yang diperoleh akan meningkat. Hal ini tentunya akan meningkatkan LDR sehingga Return on Asset bank juga meningkat.

\subsubsection{CAR merupakan variabel dominan berpengaruh terhadap ROA}

Jika dibandingkan kontribusi dari ketiga variabel bebas terhadap variabel terikat, maka ditemukan kontribusi terbesar diperoleh pada pengaruh CAR terhadap ROA dengan besaran kontribusi sebesar 0.171 atau sebesar $17.10 \%$ yang menunjukkan kontribusi terbesar jika dibandingkan dengan variabel bebas lainnya (BOPO dan LDR). Berdasarkan hasil tersebut, maka dapat dinyatakan bahwa hipotesis keempat yang menyatakan bahwa CAR berpengaruh dominan terhadap ROA dinyatakan terbukti atau diterima.

\section{Kesimpulan dan Rekomendasi}


Berdasarkan hasil pengujian dan pembahasan hasil penelitian mengenai pengaruh CAR, BOPO dan LDR terhadap ROA, maka dapat ditarik kesimpulan bahwa CAR berpengaruh positif signifikan terhadap ROA (Ha). Semakin besar CAR, maka semakin besar kesempatan bank dalam menghasilkan laba karena dengan modal besar yang dimiliki oleh bank maka pihak manajemen bank memiliki banyak pilihan dalam menempatkan dananya ke dalam aktivitas investasi yang menguntungkan. CAR berpengaruh negatif signifikan terhadap ROA (H0). Negative signifikannya hasil penelitian ini menunjukkan bahwa BOPO yang rendah terbukti mampu meningkatkan return on asset (ROA) Bank BUMN. LDR berpengaruh negatif signifikan

Tabel 7 Hasil Uji Regresi Berganda

\begin{tabular}{llcccccc}
\hline Model & Std. Error & $\begin{array}{c}\text { Standardized } \\
\text { Coefficients } \\
\text { Beta }\end{array}$ & $\mathrm{t}$ & Sig. & Hipotesis & Keputusan. \\
\hline 1 & (Constant) & 3.153 & & 3.326 & .001 & & \\
& $\mathrm{X}_{1}($ CAR $)$ & .829 & .319 & 2.503 & .016 & + Sign. & Diterima \\
& $\mathrm{X}_{2}(\mathrm{BOPO})$ & .458 & -.633 & -4.513 & .000 & - Sign. & Diterima \\
& $\mathrm{X}_{3}(\mathrm{LDR})$ & .193 & -.307 & -3.167 & .002 & + Sign. & Ditolak \\
\hline
\end{tabular}

terhadap ROA (H0), hasil penelitian ini memberikan penjelasan bahwa semakin kecil jumlah dana yang disalurkan kepada nasabah dalam bentuk kredit maka jumlah dana yang menganggur berkurang dan penghasilan bunga yang diperoleh akan meningkat. Hal ini tentunya akan meningkatkan LDR sehingga Return on Asset bank juga meningkat. Penelitian ini memiliki keterbatasan sehingga disarankan bagi penelitian lanjutan untuk memperluas ruang lingkup penelitian, karena masih banyak sektor yang dapat dijadikan penelitian agar hasil penelitian dapat digeneralisasikan dan dengan menambah tahun pengamatan, kemudian peneliti lanjutan juga diharapkan menganalisis return on asset dengan menambahkan variabelvariabel lain yang mempengaruhi profitabilitas perbankan.

\section{DAFTAR PUSTAKA}

Bank Indonesia (2012). Peraturan Bank Indonesia Nomor 14/ 15 /PBI/2012 Tentang Penilaian Kualitas Aset Bank Umum

Darmawi, H. (2014). Manajemen Perbankan Cetakan Ketiga. Jakarta: Bumi Aksara.

Dendawijaya, L. (2009). Manajemen Perbankan Edisi Revisi. Ciawi Bogor, Ghalia Indonesia.

DeYoung, R., \& Rice, T. (2004). Noninterest income and financial performance at US commercial banks. Financial Review, 39(1), 101-127.
Fajri, R., \& Seftarita, C. (2019). PENGARUH CAR, BOPO, DAN LDR Terhadap Profitabilitas Bank Di Indonesia. Jurnal Ilmiah Mahasiswa Ekonomi Pembangunan, 3(4), 767-775.

Ghozali, Imam. (2011). Aplikasi Analisis Multivariate Dengan Program SPSS. Semarang: Badan Penerbit Universitas Diponegoro

Gustin, A. P. (2019). Pengaruh Kecukupan Modal, Risiko Kredit, Likuiditas Dan Beban Operasional Terhadap Profitabilitas (Studi Empiris pada Bank BUMN Di Indonesia Periode 2013-2017) (Doctoral dissertation, Universitas Muhammadiyah Surakarta).

Husnan, S. (2013). Manajemen Keuangan Edisi Keempat. Yogyakarta: BPFE.

Kasmir. (2014). Dasar-dasar Perbankan. Edisi Revisi 2008. Jakarta : PT Raja. Grafindo Persada

Kinerja Bank BUMN dan Swasta (2019) https://keuangan.kontan.co.id/, 2019

Kokoh, T. A., Monica, C., Pragana, D. P., Sinaga, M. G. M., \& Wulandari, B. (2019). Pengaruh Cash Turnover, Net Interest Margin, Loan To Deposit Ratio, Operational Efficiency And Cost Efficiency (Bopo) Terhadap Return On Asset (Roa) Pada Perbankan Konvensional Yang Terdaftar Di Bursa Efek Indonesia Periode 2012-2016. Jurnal Akrab Juara, 4(2), 143-158.

Purnamasari, Y., \& Mudakir, B. (2019). Determinan Profitabilitas Bank Umum 
Konvensional Di Indonesia (Kasus: Bank Kategori BUKU 4) (Doctoral dissertation, Fakultas Ekonomika dan Bisnis).

Putra, P. S., \& Juniarti, S. (2019). Analisis Pengaruh Loan To Deposit Ratio (Ldr), Non Performing Loan ( $\mathrm{Npl})$, Dan Biaya Operasional Pendapatan Operasional (Bopo) Terhadap Return On Asset (Roa) Pada Bank Umum Milik Negara. Jurnal Media Wahana Ekonomika, 13(3).

Rachmawati, S., \& Marwansyah, S. (2019). Pengaruh Inflasi, Bi Rate, CAR, NPL, BOPO Terhadap Profitabilitas Pada Bank BUMN. Jurnal Mantik Penusa, 3(1, Juni), 117-122.

Rahmah, M. N. (2019). Pengaruh kecukupan modal, risiko pembiayaan, dan Ukuran Perusahaan terhadap Profitabilitas (Studi Empiris pada Bank Umum Syariah di Indonesia Periode 2014-2017) (Doctoral dissertation, Universitas Muhammadiyah Surakarta).

Rivai, V., Basir, S., Sudarto, S., \& Veithzal, A. P. (2013). Commercial bank management: Manajemen perbankan dari teori ke praktik. Jakarta: PT Raja Grafindo Persada.

Sari, D. N., Sriwidodo, U., \& Indriastuti, D. R. (2019). Analisis Pengaruh Non Performing Loan, Loan To Deposit Ratio, Dan Capital Adequacy Ratio Terhadap Return On Assets Pada Bank Bumn Di Indonesia. Jurnal Ekonomi Dan Kewirausahaan, 18(3).

Setiawan, M., Amboningtyas, D., \& Aryanti, R. P. (2019). Analysis Of Non Performing Loan (Npl), Capital Adequacy Ratio (Car), And Operational Costs With Operational Income (Bopo) That Impact On Profitability (Case Study In PT. BPR In Semarang Area 2013-2017). Journal of Management, 5(5). 